\title{
The Migration Intentions of Young Adults in Europe: A Comparative, Multi-Level Analysis ${ }^{1}$
}

\author{
Allan M Williams*, Calvin Jephcote, Hania Janta, Gang Li \\ School of Hospitality and Tourism Management, University of Surrey, UK
}

\begin{abstract}
Research on migration intentions is relatively fragmented, traditionally drawing conclusions from relatively small survey samples, focussing on individual countries, or relying on public opinion polls which provide very few explanatory variables. This paper addresses these limitations by developing a multi-level model of an extensive range of macro, meso and micro determinants of migration intentions across different time frames. The paper utilises an online panel survey of 20,473 non-student respondents aged 16-35 from 9 EU countries.

Ordinal multi-level modelling, with post-stratification weighting, is used to determine the key drivers of, and barriers to, migration intentions in both a pan-European model, and nine separate national-scale models. The findings confirm the significance of macro, meso and micro factors. While socio-economic factors emerge as powerful explanatory factors, non-pecuniary factors are also important, including sensation seeking. There are broad similarities in the findings across the separate national-level models, but also differences in the relative importance of socio-economic, gender, and personality factors. Migration intentions were highly dependent on the decision-making time frame: 17 per cent of respondents over one year, but 30 per cent over five years, are likely to migrate or to have made firm plans to migrate. The rank ordering of the countries challenges the notion of there being a simple differentiation between the newer and older member states of EU.
\end{abstract}

Keywords: youth migration; migration intentions; European migration; time frames; multilevel modelling

\section{INTRODUCTION}

There is a long-established research interest in migration intentions which tends to peak at times of either major economic crises or of significant shifts in migration regimes, such as the eastern enlargement of the European Union (Fassmann and Hintermann, 1998). This has been given renewed urgency by the high and increasing levels of youth migration in Europe, following the 2008+ economic crisis (Cairns, 2014; van Mol, 2016). Debates about the likely levels of future migration have also been fuelled more recently by the 2016 Brexit referendum in the UK (Pietka-Nykaza and McGhee 2016), which took place against a background of antimigration political, media, and popular discourses, which emphasised perceived negative implications of the EU's freedom of movement provisions for national border controls. In general, there is more speculation than evidence on this contentious topic.

Even where empirical evidence does exist on future mobility intentions, it tends to be characterised by fragmentation due to methodological diversity, small samples and the difficulties of extrapolating from studies of particular countries. Using inconsistent terminology, past studies examine 'plans', 'desires', 'intentions' and 'wishes' to migrate under

\footnotetext{
${ }^{1}$ The paper should be cited as follows:

Williams AM, Jephcote C, Janta H, Li G. The migration intentions of young adults in Europe: A comparative, multilevel analysis. Population, Space and Place. 2017; e2123. https://doi.org/10.1002/psp.2123

* Correspondence to: Allan M. Williams, School of Hospitality and Tourism Management, University of Surrey, Guildford, Surrey, GU2 7HX, UK. Email: allan.williams@ @urrey.ac.uk
} 
various time scales; in the next one, two, three, five or ten years. This makes previous empirical research on mobility intentions challenging to compare or to derive meaningful policy implications. Moreover, the renewed interest in recent years in the topic of future migration tends to focus on student mobility (e.g. Cairns and Smyth, 2011; Cairns, 2014), with relatively few studies of non-students. Examining intentions to migrate is important for understanding the actual migration decision-making process; empirical evidence suggests a strong link between the intended and actual decision (Van Dalen and Henkens, 2008). However, Fassmann and Hintermann (1998) emphasise that determining the potential for migration is a complicated issue and, especially due to political sensitivities, requires a rigorous research approach.

This paper aims to contribute to this research agenda by providing a detailed comparative analysis of migration intentions, across different time frames, for nine countries representing a range of migration contexts within the EU. These countries represent a range of contrasting socio-economic, migration, and EU membership contexts: Germany, Ireland, Italy, Latvia, Romania, Slovakia, Spain, Sweden and UK. Our analysis draws on a large-scale panel survey undertaken in these nine countries in late 2015 as part of the EU H2020 project YMOBILITY. The dataset analysed in this paper consists of 20,473 non-student Europeans aged 16-35 and is supplemented by secondary data on key socio-economic indicators to ensure the robustness of the analysis. Multi-level regression is used to analyse the key motives and barriers for migration among young individuals from the nine countries and their intention to migrate in the next one and five years. More specifically the paper addresses three main questions:

1. To what extent do different degrees of firmness in intentions to migrate vary across different time frames for a range of countries representing diverse migration contexts?

2. What is the relative importance of the potential macro, micro and meso-level determinants of intentions to migrate?

3. How do the determinants of the intention to migrate vary across different European countries representing markedly different migration contexts?

The paper first reviews the literature on migration intentions, including the measurement of the levels of intentions to migrate, and the determinants of these intentions, understood in terms of macro, meso and micro factors (Massey et al., 1993). It then outlines the methodology, before presenting and discussing findings revealing the intentions of young Europeans over both one-year and five-year time frames.

\section{LITERATURE REVIEW}

There is considerable debate in the migration literature about whether migration intentions/aspirations predict actual behaviour (Epstein and Gang, 2006: 653; Van Dalen and Henkens, 2007, 2008; Cairns and Smyth, 2011; Cairns et al. 2013). Ajzen (1991) and others have conceptualised this in terms of the locus of control, while more recently Van Dalen et al. (2005) have highlighted the potential importance of self-efficacy as the key determinant of who actually migrates. Notwithstanding these reservations, there has been renewed interest in recent years in attempts to measure individuals' migration intentions.

A review of the literature indicates that very recent publications tend to focus on student groups rather than on the general population. Both are discussed here although we note that there may be differences between those attending a university and other groups - such as graduates, those in employment and those either seeking or not seeking work. The group enrolled in education tends to express a higher willingness to be mobile. Van Mol (2016) 
attributes this to the fact that students are freer from the constraints of everyday life and have fewer responsibilities. In their study of students' mobility intentions in Northern Ireland, Cairns and Smyth (2011) found that more than half of those surveyed are considering living outside Northern Ireland in future. A later study found that 72 per cent of students in the Republic of Ireland and 52 per cent in Northern Ireland have mobility intentions (Cairns 2014). Although 'the mobility question' and the precise terminology used in the various surveys widely differ, studies using student samples tend to identify higher mobility intentions. In contrast, potential migration rates are significantly lower among working-age adults (see e.g. Tabor et al., 2015 on New Zealand).

In an attempt to explain such high variations in mobility intentions, Docquier et al., (2014) reveal in their large cross-country study that college-educated individuals are more likely to become actual migrants because of better opportunities to realise their migration potentials. What prevents other groups from translating their plans into actual migration may be the lack of certain personal characteristics, or of familial constraints - important aspects which we return to later. In one of the rare studies examining whether intentions are in fact good predictors of future emigration, Van Dalen and Henken (2008) discovered that 24 per cent of those who had stated an intention to emigrate had actually emigrated from the Netherlands within two years. However, there are still relatively few studies which compare potential and actual mobility.

These different findings reflect not only the importance of the territorial and temporal contexts, but also the variable methods that have been used to estimate intentions. There are variations in the size of the samples, from a few hundred to several thousand, and in their representativeness, notably whether they include only students or seek to represent an entire age group. There are variations in measures of the firmness of intentions, which range from simple dichotomous responses to those which differentiate between unspecified intentions and having made firm plans to migrate. There are also differences in the time frames between those which do not specify a precise time frame, and those which specify one or more time periods within which the proposed migration will occur. Table 1 is a schematic synthesis of this literature and the methods used. Turning from the measurement of the levels of intentions to migrate to the determinants of these intentions, it is possible to draw on a more general literature pertaining more to actual migration than to intentions. The determinants can be understood in terms of macro, meso and micro factors (Massey et al., 1993).

The research on the macro level mostly focuses on economic inequalities and macroeconomic trends. The neoclassical approach (for example Todaro, 1969) emphasises disparities in wages and employment at the regional and international scales. Using data from the 2008 Eurobarometer survey, Otrachshenko and Popova (2014) demonstrate that the intention to migrate is indeed affected by macro-economic variables. Combining the impact of life satisfaction and macro-economic variables reveals a greater propensity to migrate among individuals from the Central and Eastern European (CEE) countries than from non-CEE countries. Hadler's (2006) study, however, using 2001 Eurobarometer survey data, points to the effects of regional disparities within and across European countries. The highest migration intentions can be observed in regions with a developmental gap compared to the overall level of a country; the higher the gap between the regional GDP and the countrywide GDP, the more willing people are to move. Surprisingly, the highest intentions to go abroad are found in highly developed countries. This raises the question of the extent to which not only the levels of migration intentions, but also their determinants, vary across different macro-regional contexts in Europe. 
Table 1. Previous studies measuring mobility intentions

\begin{tabular}{|c|c|c|c|c|c|c|}
\hline Authors & Aim & Country & $\mathbf{N}$ & Sample/population & The migration intention question & Analytical Method \\
\hline $\begin{array}{l}\text { Fassmann \& } \\
\text { Hintermann } \\
\quad(1998)\end{array}$ & $\begin{array}{c}\text { To identify the } \\
\text { migration potential } \\
\text { among CEE countries }\end{array}$ & $\begin{array}{l}\text { Czech } \\
\text { Republic, } \\
\text { Hungary, } \\
\text { Poland and } \\
\text { Slovakia }\end{array}$ & 4,392 & $\begin{array}{l}\text { Gallup Survey. A quota sample } \\
\text { out of the total population over } \\
\text { the age of } 14 \text {. Questionnaire } \\
\text { administered face to face in the } \\
\text { respondents' homes in } 1996 .\end{array}$ & $\begin{array}{l}\text { 'Potential' migration is differentiated into three categories: very general, } \\
\text { potential and 'real' potential. ('Yes'/'No') } \\
\text { Three questions: I have thought of going abroad/ I have at least gathered } \\
\text { information about the target country in question/ I have already applied for a } \\
\text { residence permit or a work permit. }\end{array}$ & Descriptive statistics \\
\hline $\begin{array}{l}\text { Van Dalen \& } \\
\text { Henkens } \\
\text { (2005) }\end{array}$ & $\begin{array}{l}\text { To examine who } \\
\text { intends to leave Africa }\end{array}$ & $\begin{array}{l}\text { Ghana, } \\
\text { Senegal, } \\
\text { Morocco } \\
\text { and Egypt }\end{array}$ & $\begin{array}{c}1,569 \\
583 \\
2,267 \\
2,940\end{array}$ & $\begin{array}{l}\text { Special purpose migration } \\
\text { surveys in 1997/1998 }\end{array}$ & $\begin{array}{l}\text { The key question probed the intentions of respondents who had never } \\
\text { emigrated before: 'Do you intend to migrate abroad?' ('yes' l'no'/'don't } \\
\text { know') } \\
\text { Timescale: Intention to emigrate within } 2 \text { years / Has taken actual steps to } \\
\text { emigrate. }\end{array}$ & Ordered probit analysis \\
\hline $\begin{array}{l}\text { Epstein \& } \\
\text { Gang (2006) }\end{array}$ & $\begin{array}{l}\text { To examine the roles } \\
\text { "other people" play in } \\
\text { influencing an } \\
\text { individual's potential } \\
\text { migration decision }\end{array}$ & Hungary & 2491 & $\begin{array}{l}\text { Those aged } 20-40 \text { in the } \\
\text { Hungarian Household Panel } \\
\text { Survey 1992-97 }\end{array}$ & $\begin{array}{l}\text { Respondents asked to specify the strength of their desire to go abroad: 'not } \\
\text { willing', 'somewhat willing', and 'willing'. } \\
\text { Explanatory variables capture past (friends worked abroad), present } \\
\text { (friends/kin abroad), and future (friends/kin planning on going abroad) } \\
\text { networks and herd effects. }\end{array}$ & Probit analyses \\
\hline $\begin{array}{l}\text { Hadler } \\
\text { (2006) }\end{array}$ & $\begin{array}{l}\text { To examine people's } \\
\text { intentions to migrate } \\
\text { aged younger than } 45 \\
\text { years }\end{array}$ & $\begin{array}{l}15 \\
\text { European } \\
\text { countries, } \\
196 \text { nuts-2- } \\
\text { regions }\end{array}$ & 7000 & $\begin{array}{l}\text { Using the Eurobarometer } \\
\text { Survey for } 2001\end{array}$ & $\begin{array}{l}\text { 'Do you think you will move in the next five years?' 'Yes'/'No' } \\
\text { Intend to move to another country within the European Union: 'Yes'/'No' }\end{array}$ & Three-level regression \\
\hline $\begin{array}{l}\text { Agadjanian, } \\
\text { et al. (2008) }\end{array}$ & $\begin{array}{l}\text { To examine young } \\
\text { people's intentions to } \\
\text { migrate abroad in } \\
\text { Kyrgyzstan, in } \\
\text { particular on } \\
\text { differences between } \\
\text { Asian and European- } \\
\text { origin ethnic groups }\end{array}$ & Kyrgyzstan & 1,535 & $\begin{array}{l}\text { Survey conducted in } 2005 . \\
\text { Sample: } 1,535 \text { aged } 18-29\end{array}$ & $\begin{array}{l}\text { The term 'intentions' is used to encompass both firm plans to migrate abroad } \\
\text { and wishes to migrate abroad: "plan" and "wish" as two types of migration } \\
\text { intentions that are similar in essence but different in strength and maturity. } \\
\text { Considering intentions to migrate permanently or temporarily. }\end{array}$ & $\begin{array}{l}\text { Logistic regression for } \\
\text { ordered outcomes to } \\
\text { analyze the maturity of } \\
\text { migration intentions - } \\
\text { multinomial logit model }\end{array}$ \\
\hline $\begin{array}{l}\text { Cairns \& } \\
\text { Smyth (2011) }\end{array}$ & $\begin{array}{l}\text { To examine } \\
\text { orientations towards } \\
\text { future geographical } \\
\text { mobility amongst }\end{array}$ & & 250 & $\begin{array}{l}\text { A questionnaire spread across } \\
\text { four different academic } \\
\text { disciplines in Northern }\end{array}$ & 'I see myself always living in Northern Ireland in the future'. ('Yes'/'No') & Chi square \\
\hline
\end{tabular}




\begin{tabular}{|c|c|c|c|c|c|c|}
\hline & $\begin{array}{l}\text { students in Northern } \\
\text { Ireland }\end{array}$ & $\begin{array}{l}\text { Northern } \\
\text { Ireland }\end{array}$ & & $\begin{array}{l}\text { Ireland's two universities, } \\
2006 / 2007 \text {. }\end{array}$ & & \\
\hline $\begin{array}{l}\text { Cairns } \\
\text { (2014) }\end{array}$ & $\begin{array}{l}\text { To examine } \\
\text { orientations towards } \\
\text { future geographical } \\
\text { mobility amongst } \\
\text { students }\end{array}$ & $\begin{array}{l}\text { Northern } \\
\text { Ireland and } \\
\text { Ireland }\end{array}$ & 400 & $\begin{array}{l}\text { Undergraduates aged between } \\
18 \text { and } 24, \text { who were studying } \\
\text { at universities in Dublin, } \\
\text { Belfast and Cork during } 2010\end{array}$ & $\begin{array}{l}\text { 'In the future, I see myself always living in Northern Ireland/Republic of } \\
\text { Ireland.' (Yes'/'No') }\end{array}$ & Chi square \\
\hline $\begin{array}{l}\text { Van Dalen \& } \\
\text { Henkens } \\
\text { (2012) }\end{array}$ & $\begin{array}{l}\text { To analyse the } \\
\text { international labour } \\
\text { migration intentions } \\
\text { amongst the Dutch } \\
\text { potential labour force }\end{array}$ & $\begin{array}{l}\text { The } \\
\text { Netherlands }\end{array}$ & 971 & $\begin{array}{l}\text { A nation-wide survey of those } \\
\text { aged } 16-60 \text { years }\end{array}$ & $\begin{array}{l}\text { 'Do you expect to work abroad for a couple of years in the next } 10 \text { years?' } \\
\text { Five categories of rankings of expectations from 'highly unlikely' to 'highly } \\
\text { likely'. }\end{array}$ & Regression analysis \\
\hline $\begin{array}{l}\text { Otrachshenk } \\
\text { o \& Popova } \\
\text { (2014) }\end{array}$ & $\begin{array}{l}\text { The impacts of } \\
\text { individual } \\
\text { characteristics and of } \\
\text { country } \\
\text { macroeconomic } \\
\text { variables on the } \\
\text { intention to migrate }\end{array}$ & $\begin{array}{l}27 \text { Central } \\
\text { and Eastern } \\
\text { European } \\
\text { (CEE) and } \\
\text { Western } \\
\text { European } \\
\text { (non-CEE) } \\
\text { countries }\end{array}$ & 24,232 & $\begin{array}{l}\text { Using the Eurobarometer } \\
\text { Survey for } 2008\end{array}$ & $\begin{array}{l}\text { 'Do you intend to move in the next five years?' } \\
\text { 'Do you intend to move within country or to another country? } \\
\text {-distinguishing three types of migration intentions; permanent international, } \\
\text { temporary international, and domestic. } \\
\text { and migration intention duration: 'How long do you expect to stay abroad?' - } \\
\text { temp and permanent }\end{array}$ & $\begin{array}{l}\text { A two-level regression } \\
\text { analysis }\end{array}$ \\
\hline $\begin{array}{l}\text { Docquier et } \\
\text { al. (2014) }\end{array}$ & $\begin{array}{l}\text { To analyse the } \\
\text { determinants of } \\
\text { potential and actual } \\
\text { migration }\end{array}$ & $\begin{array}{l}138 \text { origin } \\
\text { countries }+ \\
30 \text { major } \\
\text { destinations }\end{array}$ & $\begin{array}{l}\text { all } \\
\text { populatio } \\
\mathrm{n}\end{array}$ & $\begin{array}{l}\text { Using information on potential } \\
\text { migrants from World Gallup } \\
\text { surveys and on actual migrants } \\
\text { from national censuses for } 138 \\
\text { origin countries }+30 \text { major } \\
\text { destinations between } 2000 \text { and } \\
2010,\end{array}$ & $\begin{array}{l}\text { 'Ideally, if you had the opportunity, would you like to move permanently or } \\
\text { temporarily to another country, or would you prefer to continue living in this } \\
\text { country?' }\end{array}$ & $\begin{array}{l}\text { The bilateral gravity-like } \\
\text { regressions }\end{array}$ \\
\hline $\begin{array}{l}\text { Van Mol \& } \\
\text { Timmerman } \\
\text { (2014) }\end{array}$ & $\begin{array}{l}\text { To examine the } \\
\text { determinants of intra- } \\
\text { European student } \\
\text { mobility in six } \\
\text { countries }\end{array}$ & $\begin{array}{l}\text { Austria, } \\
\text { Belgium, } \\
\text { Italy, } \\
\text { Norway, } \\
\text { Poland, } \\
\text { UK }\end{array}$ & 5654 & $\begin{array}{l}\text { An online survey and in-depth } \\
\text { interviews and focus groups } \\
\text { with non-mobile as well as ex- } \\
\text { mobile students }\end{array}$ & $\begin{array}{l}\text { 'Do you intend to spend some time abroad during the remainder of your } \\
\text { degree?' (Yes'/ 'No') }\end{array}$ & Binary logistic regression \\
\hline
\end{tabular}




\begin{tabular}{|c|c|c|c|c|c|c|}
\hline $\begin{array}{l}\text { Van Mol } \\
\text { (2016) }\end{array}$ & $\begin{array}{l}\text { To analyse mobility } \\
\text { intentions amongst } \\
\text { young people aged } \\
16-30 \text { in all member } \\
\text { states of the EU }\end{array}$ & $\begin{array}{l}\text { All EU } \\
\text { member } \\
\text { states }\end{array}$ & 13,078 & $\begin{array}{l}\text { Representative sample of } \\
\text { young people aged } 16-30 \text { in all } \\
\text { member states of the EU, using } \\
\text { secondary data from Flash } \\
\text { Eurobarometer } 395 \text {. A multi- } \\
\text { stage random (probablistic) } \\
\text { sample was drawn in each } \\
\text { member stat of some 500 } \\
\text { individuals who were surveyed } \\
\text { through Computer Assisted } \\
\text { Telephone Interviews (CATI) } \\
\text { in } 2014\end{array}$ & $\begin{array}{l}\text { 'You want to study, undergo training or work in another EU country than } \\
\text { [country]' = 'Yes'/ 'No' }\end{array}$ & $\begin{array}{l}\text { Multi-level binary logistic } \\
\text { regression }\end{array}$ \\
\hline $\begin{array}{l}\text { Tabor et al. } \\
\text { (2015) }\end{array}$ & $\begin{array}{l}\text { To examine New } \\
\text { Zealand-born } \\
\text { working-age adult } \\
\text { participants' mobility } \\
\text { intentions }\end{array}$ & $\begin{array}{l}\text { New } \\
\text { Zealand }\end{array}$ & 205 & $\begin{array}{l}\text { Participants recruited through } \\
\text { online forums in 2012/2013 }\end{array}$ & $\begin{array}{l}\text { 'Are you currently planning or considering moving to another country?' } \\
\text { 'Yes'/'No' } \\
\text { Timescale: Within the next year, between 1-3 years from now, } 3 \text { or more } \\
\text { years from now. } \\
\text { Considering migration for the past } 1-3 \text { years / for more than } 3 \text { years, and a } \\
\text { less than a year. }\end{array}$ & $\begin{array}{l}\text { Logistical regression } \\
\text { techniques }\end{array}$ \\
\hline $\begin{array}{l}\text { Balaz et al. } \\
\text { (2015) }\end{array}$ & $\begin{array}{l}\text { To examine the } \\
\text { decision weights for } \\
\text { eight attributes of } \\
\text { potential destination } \\
\text { countries }\end{array}$ & Slovakia & 157 & $\begin{array}{l}\text { Experimental research with } \\
\text { university students and recent } \\
\text { graduates. }\end{array}$ & $\begin{array}{l}\text { Participants presented with a hypothetical intra-company transfer to a foreign } \\
\text { country for three years. }\end{array}$ & Mann Whitney U test \\
\hline
\end{tabular}


Economic factors can also act as a major barrier to mobility (Van Mol and Timmerman, 2014). Financial reasons deter European students in Austria, Belgium, Italy, Norway, Poland, and the UK from studying abroad. Much recent research (Halfacree, 2004) emphasises that a range of non-economic macro-scale factors may also influence migration. These are explored by Baláž et al. (2016) in a study of complex migration decision-making among young people in Slovakia (see also Table 1). While the economic characteristics of countries are nearly always the most important in decision-making, Baláž et al. also find evidence of substantial weight being given to non-economic factors such as health, crime, and personal freedom and security. Another important macro-scale factor is the level of dissatisfaction with the public domain in the home country or regions (van Dalen and Henkens, 2008), so that issues such as corruption can have a considerable but variable influence on migration intentions across Europe.

Meso-level factors focus particularly on access to knowledge about living abroad. This can be related to various personal, community and diaspora ties, work-based networks as well as recruitment channels for both those in employment and for students. Networks, including those established online, play a key role in migration decisions (Boyd, 1989; Epstein and Gang, 2006), by facilitating access to accommodation and employment, easing the initial stress after the arrival. Young people with mobility intentions are significantly more likely to have siblings or friends who live abroad (Cairns and Smyth, 2011). The strength, size and type of networks vary between students, skilled and unskilled workers, with the last group relying mostly on informal networks. Networks are not only facilitators but also act as barriers to potential mobility (van Dalen and Hankens, 2012), especially in the form of strong attachments to local communities and the role of family relationships in both encouraging and discouraging international mobility (Cairns, 2014).

There are three main groups of micro-level or individual factors which shape migration: socio-economic, demographic, and psycho-social or personality. While neoclassical perspectives based on wages and unemployment can be applied to the analysis of individual decision-making, human capital theories are more commonly applied at this scale (Sjaastad, 1962). In this perspective, migration is understood as an investment decision to realise differential returns on human capital in different economic spaces, or as a means to acquire human capital with a view to enhanced lifetime income. Given that education is often used as a surrogate measure of human capital, it is not surprising that there is evidence, for example in Central and Eastern Europe, of higher mobility intentions amongst the more educated (Fassmann and Hintermann, 1998; Epstein and Gang, 2006). More recent research provides a more nuanced perspective, demonstrating that social class background is also an important factor, with higher rates of potential mobility amongst those from the topmost socio occupational groups, at least in the case of student mobility (King et al., 2010). A different economic perspective is provided by the role of finance as a major barrier to students participating in European student mobility (Van Mol and Timmerman, 2014).

Turning to socio-demographic factors, there is mixed evidence about the role of gender. There is a general agreement among scholars using whole population samples that males are significantly more likely to express mobility intentions (Fassmann and Hintermann, 1998; Epstein and Gang, 2006). But studies of specific groups' migration behaviour (e.g. UK outward Erasmus students, King et al., 2010) indicate that women are disproportionately important in student mobility flows. And yet, other more recent studies of intended future migration amongst students suggest that men are relatively more numerous (Cairns and Smyth, 2011), possibly because of family and other social constraints (Van Mol, 2016). There is agreement, 
however, that the likelihood of migration decreases with age (Epstein and Gang 2006; Otrachshenko and Popova, 2014; Van Mol, 2016), marriage (Gubhaju and De Jong, 2009; Otrachshenko and Popova, 2014), and childbearing (Hadler, 2006; Agadjanin et al., 2008), although how these categorisations vary within the young-adult group is less well documented. Previous experience of living abroad is another important factor which is associated with higher rates of mobility (Fassmann and Hintermann, 1998: 66; Epstein and Gang, 2006; Tabor et al., 2015). For example, Van Mol (2016) demonstrates that individuals with such experiences are more than twice more likely to intend to migrate than those lacking this experience, while Handler (2006) shows that the farther individuals have previously moved, the farther they are likely to intend to move. Experimental research also suggests that individuals with histories of international mobility cope better with potential overload of, and imperfect, information about different contexts (Balaz et al., 2016). They are also more likely to engage in multiple or repeat migrations, according to Ciobanu's (2014) research on Romanians and Main's (2013) work on Polish women.

Recent research focuses less on socio-economic and socio-demographic characteristics, and more on personality factors. Boneva and Frieze (2001) introduce the notion of 'migrant personality': compared to non-migrants, migrants tend to be more work-orientated and to have higher achievement motivations, whilst 'stayers' are more tied to their families and home-based social networks and community attachments (Cairns, 2009; 2014; Cairns and Smyth, 2011). These initial formulations have been extended in several directions. Van Dalen and Henkens (2007) indicate that personality traits such as self-efficacy and sensation-seeking tend to be critical predictors of the migration intentions of Dutch citizens. Other studies indicate the importance of being more open to experience (Jokela, 2009) or being persistent or contentious (Tabor and Milfont, 2011; Tabor et al., 2015). Identities have also been recognised as important determinants of migration and/or migration intentions. Those who have strong, or are proud of their, national identities, are less likely to migrate (Bjarnason and Thorlindsson, 2006; Van Dalen and Henkens, 2012). The same applies to students in Northern Ireland who have strong local identities (Cairns and Smyth, 2011; Cairns, 2014). Finally, a relatively new strand of research indicates that risk tolerance/aversion and perceived competence to manage risk are important determinants of the willingness to migrate (Williams and Baláž, 2012).

To sum up, while there is a growing body of research on migration intentions, a review of the literature suggests that much of it is fragmented and that there are three major gaps which need to be addressed. These generate the three main research questions addressed by this paper, relating to time frames, the determinants of intentions to migrate, and how these vary across European countries and/or macro-regions.

\section{METHODOLOGY}

\section{Dataset - sample and weighting}

This study takes a quantitative approach, based predominantly on primary data, supplemented by some secondary data on key socio-economic indicators. The primary data were collected in a large-scale online panel survey, specially commissioned from a major market research organisation, GfK Significance (Belgium). Data collection took place between November 2015 and January 2016, in nine European countries representing a range of migration and socioeconomic conditions, and histories of EU membership: Germany, Ireland, Italy, Latvia, Romania, Slovakia, Spain, Sweden and UK. The datset analysed consists of 20,473 non-student respondents aged 16-35, this being the age-band which we nominate to cover 'youth' and 
'young adult' respondents. The survey, designed by the authors, includes respondents' demographic characteristics, past travel and migration experiences, current quality of life and personality evaluation, perceived importance of key motives and barriers for migration, and intention to migrate. The perception/evaluation and intention questions are measured on 5point scales. Specifically, the 'mobility question' asked about medium-term (within one year) and longer-term (within five years) intentions to migrate for a period of at least six months: this can include return migration intentions, in the case of migrants currently living outside their countries of birth. The answers, provided in the form of Likert-scale type questions, distinguish different levels of firmness in migration intentions.

Since an online panel survey approach was adopted for primary data collection, the sample may not be fully representative of the population. Therefore, post-stratification survey weights were constructed based on the latest micro-region population data (NUTS 3 ) from the Eurostat census records. The stratification uses various strata (including age-group, gender, educational level and urban-rural division) which are known to influence migration.

To supplement the primary survey data, a number of socio-economic indicators have also been collected for 2015 at the macro-scale, the national, and the NUTS1 and NUTS3 regional levels. These include, for example, 'Life expectancy', 'Unemployment', and 'Gross Domestic Product Purchasing Power Standards (GDP-PPS) in €’ (Eurostat Database, 2017).

\section{Method of analysis}

Multi-level regression modelling with 'Post-Stratification' (MRP) is used in this study to analyse the key drivers and barriers (i.e., independent variables) of pan-European youth migration intentions for the next 1 and 5 years, respectively (i.e., the dependent variables). A pan-European model with the full dataset and nine country-specific models with respective national datasets are estimated to identity key common factors as well as country-specific factors that affect European young people's migration intentions.

Multi-level regression models are a class of statistical models developed for the analysis of data structures with nested (or hierarchical) sources of variability, and can therefore correctly handle both individual and aggregated information. Multi-level data structures exist through hierarchical spatial (e.g., national or NUTS0 and regional/NUTS1 in this study) and non-spatial (e.g., age, gender, education in this study) group influences on an outcome (i.e., migration intention in this study). MRP begins by using multi-level regression to model individual survey responses as a function of demographic and geographic predictors, using the dataset to partially pool respondents by spatial and sub-population ecological groups. Post-stratification weights are then used to correct estimates, ensuring that the surveyed data reflects actual population structures. This is a well-established approach in the social and political sciences (Lax and Phillips, 2009a; 2009b; Ghitza and Gelman, 2013). Table 2 presents the hierarchical structures of the estimated models in this study. The Level-2 spatial structures above are constructed to abide with Hox's (1998) 50/20 rule for multi-level models with cross-level interaction designs: 50 hierarchical groups each constructed from 20 or more observations.

Given the nature of the dependent variables, this study employed ordinal multi-level regression models, in particular the most widely employed 'Proportional-Odds Cumulative Logit' model (Agresti, 2002; Finch et al., 2014;), using the 'ordinal 06-28' [R] package (Christensen, 2015). Beneficially, this approach allows for the interpretation of the regression 
variables on a binary scale, from 0 (Low) to 1 (High), while taking into account the complete set of responses in the structured dataset.

Table 2: Pan-European and national multilevel model hierarchical structures

\begin{tabular}{|l|l|l|l|l|}
\cline { 2 - 5 } \multicolumn{1}{c|}{} & $\begin{array}{l}\text { PAN- } \\
\text { EUROPEAN }\end{array}$ & ES/RO/SE & DE/IT/UK & IE/LV/SK \\
\hline $\begin{array}{l}\text { Level-1 } \\
\text { (Demographic) }\end{array}$ & Sub-populations & Sub-populations & Sub-populations & Sub-populations \\
\hline Level-2 (Spatial) & $\begin{array}{l}\text { NUTS 1: Macro- } \\
\text { region }\end{array}$ & $\begin{array}{l}\text { NUTS 3: Micro- } \\
\text { region }\end{array}$ & NUTS 2: Region & $\begin{array}{l}\text { NUTS 3: Micro- } \\
\text { region }\end{array}$ \\
\hline Level-3 (Spatial) & NUTS 0: National & $\begin{array}{l}\text { NUTS 1: Macro- } \\
\text { region }\end{array}$ & $\begin{array}{l}\text { NUTS 1: Macro- } \\
\text { region }\end{array}$ & \\
\hline
\end{tabular}

Note: ES: Spain, RO: Romania, SE: Sweden, DE: Germany, IT: Italy, IE: Ireland, LV: Latvia, and SK: Slovakia.

Before running the regression analysis, the necessary data processing is performed. Firstly, iterative regression imputation is conducted to replace missing values (Gelman and Hill, 2006: 539). Secondly, all numeric independent (X) variables undergo a process known as Grand Mean Centring (GMC) so the slope between predictor and response remains unchanged, but the interpretation of the intercept (response when $X_{N}=0$ ) now defines the outcome magnitude for the expected (mean) value of a predictor value. Thirdly, to address the scaling issue, the centred predictors are divided by 2 standard deviations to allow for all coefficients (including the untransformed binary and categorical coefficients) to be roughly interpreted on a common scale, except for the intercept, which now corresponds to the average predicted outcome with all inputs at their mean (Gelman and Hill, 2006). Lastly, to handle the potential multi-collinearity problem between candidate explanatory variables, the Variance Inflation Factor (VIF) diagnostic is conducted and all variables with VIF scores above 5 were removed (Schuenemeyer and Drew, 2011).

\section{FINDINGS AND DISCUSSION}

\section{One-year versus five-year migration intentions}

The paper first evaluates the extent to which different degrees of firmness in migration intentions vary across two time frames, for our nominated range of countries representing differentiated migration contexts. Figures 1 and 2 present the distribution of one- and five-year migration intentions in the national and pan-European samples. Overall, 17 per cent of respondents in the pan-European sample consider they are likely to migrate, or have even made concrete plan to migrant, within a year. The results vary among the nine survey countries. The respondents in Ireland, Slovakia and Latvia show the lowest intention (13\%), while the respondents in Romania show the highest intention (21\%), followed by Italy (20\%) and Spain $(19 \%)$. As would be expected, there are higher levels of migration intentions over five years. Overall, 30 per cent of the respondents are either likely to migrate or have already made concrete plans. Understandably, individuals have more time to prepare and plan (especially financially) over the longer time frame. Again, broadly similar national differences can be observed: Romanian respondents still demonstrate the highest migration intention in five years (41\%), followed by Italy (39\%) and Spain (35\%). Slovakian respondents display the lowest intention to migrate in five years (22\%), followed by the respondents from the UK $(25 \%)$, Ireland and Latvia (both 26\%). Further insights into the underlying reasons for these national differences are provided by the following analyses. 
Figure 1: Intentions of persons aged 16-35 years, to move abroad for a period of at least 6 months within the next year (1-Year Intentions)

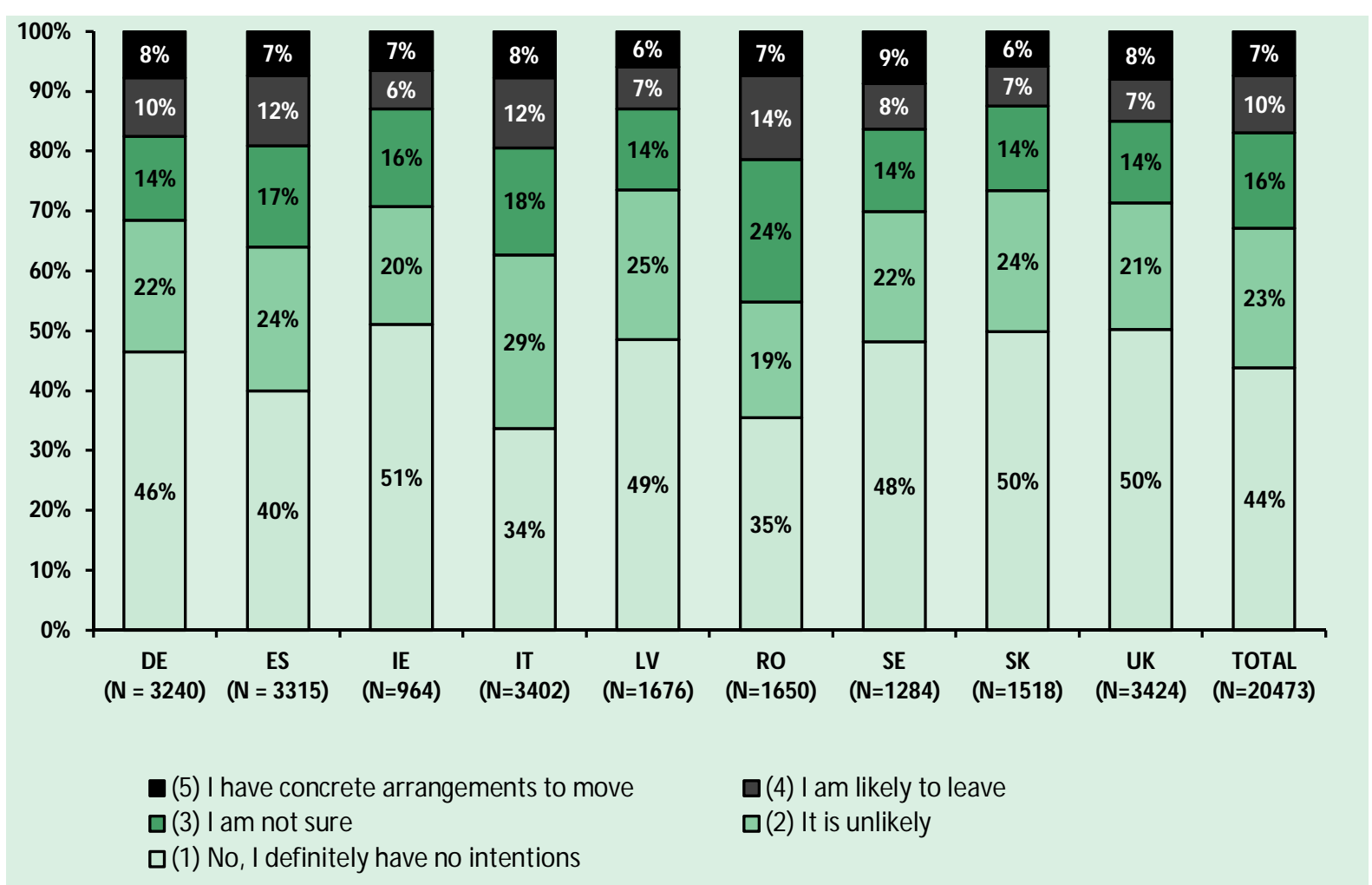

Figure 2: Intentions of persons aged 16-35 years, to move abroad for a period of at least 6 months within the next five years (5-Year Intentions)

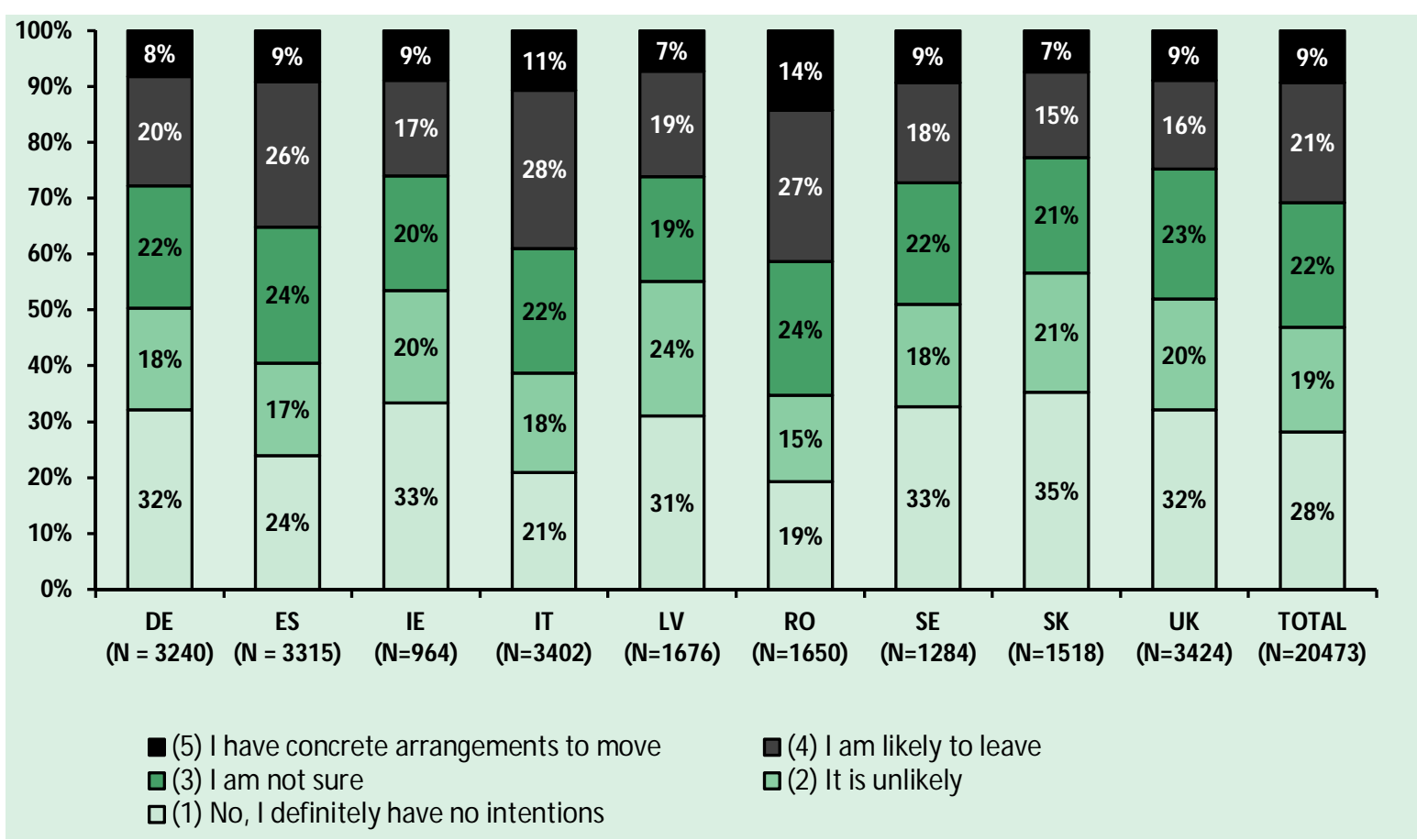


Figure 3: Hierarchical cluster analysis, providing a cross-country comparison of responses for migration intent and candidate determinants of identity, lifestyle and migratory influences. Cluster Method: "Ward D2", Distance = "Correlation", P-Values (\%) = "Approximately unbiased (AU)"

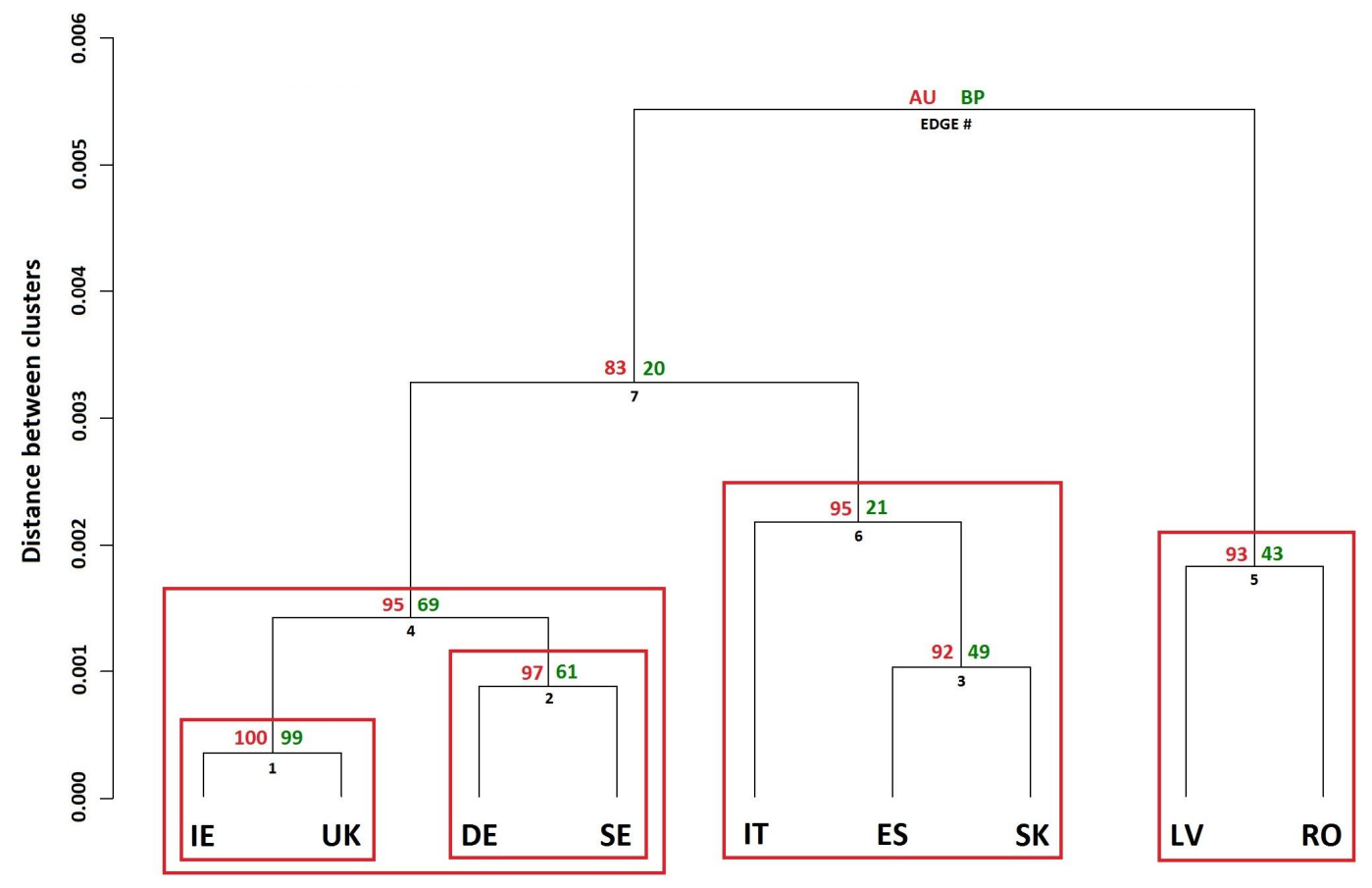

Figure 3 provides a cross-country comparison of responses to the wider survey in the form of a hierarchical cluster analysis dendogram, using the 'Pvclust 2.0' [R] package (Suzuki \& Shimodaira, 2006). The analysis considered the two intention measures in a numeric form (15), and 36 candidate x-variables numerically exploring themes of identity, lifestyle and migratory influences. Probability values for cluster structures were defined by 10,000 iterations of multiscale bootstrap resampling, presented as bootstrap probability (BP) and approximately unbiased (AU) p-values. Detailed clusters structures are significant at the $90 \%$ unbiased significance level.

The cross-country comparison of the raw survey data indicates that shared differences in response exist between (1) Northern and (2) Southern-Eastern European countries, which can be separated into the following four sub-groups: (1a) Ireland and United Kingdom; (1b) Germany and Sweden; (2a) Latvia and Romania, (2b) Italy, Spain and Slovakia. While indicating broad macro regional differences relating to socio-economic and migration conditions, as well as histories of access to the EU freedom of movement space, there are also important differences between the Eastern member states.

\section{Pan-European analysis of determinants}

The Nagelkerke pseudo- $\mathrm{R}^{2}$ measures for the pan-European ordinal weighted multilevel models of (a) 1-year and (b) 5-year migration intentions, indicate that the person-specific (behavioural and demographic) measures, secondary sub-population variables, and hierarchical structures explain 25-27 per cent of the models' variation (Table 3). The first Chi-Square Likelihood Ratio compares the full model to the Null (Intercept only) model, to ensure that any gains in predictive power of the final model are worth the added complexity. The test confirms the 
overall statistical significance of the model $(\mathrm{P}<0.001)$. It is possible to conclude that a moderate, but reliable, relationship has been modelled. The second Chi-Square Likelihood Ratio ( $\mathrm{P}<0.001)$ confirms that the inclusion of hierarchical structures is appropriate for both data sets (Galwey, 2006: 213-214).

Table 3: Statistical summary of the Pan-European ordinal weighted multilevel models for (a) 1year, and (b) 5-year migration intentions

\begin{tabular}{|c|c|c|c|}
\hline & \multirow{3}{*}{$\begin{array}{c}\begin{array}{c}\text { 1-Year } \\
\text { Intentions }\end{array} \\
20,473\end{array}$} & \multirow{3}{*}{$\begin{array}{c}\begin{array}{c}\text { 5-Year } \\
\text { Intentions }\end{array} \\
20,473\end{array}$} \\
\hline & & & \\
\hline \multirow[b]{2}{*}{ Model Description } & Observations (N) & & \\
\hline & Log Likelihood & -27096.988 & -29633.94 \\
\hline Pseudo R-Squared Measures & Nagelkerke's $R^{2}(1991)$ & 0.25 & 0.27 \\
\hline \multirow{2}{*}{$\begin{array}{l}\text { Chi-Square Likelihood Ratio } \\
\text { (P-Value) }\end{array}$} & $\begin{array}{l}\text { 1. Full Model vs. Null (Intercept) } \\
\text { Model }\end{array}$ & $<0.001 * * *$ & $<0.001 * * *$ \\
\hline & 2. Hierarchical Effects & $<0.001 * * *$ & $<0.001 * * *$ \\
\hline
\end{tabular}

\section{Fixed effects}

Table 4 provides a comprehensive description of the fixed parameters from the pan-European models. The final check ensures that the proportional odds assumption is tenable, with a consistent relationship existing between all sequentially paired groups of the models' ordinal outcome. For both models, the threshold intercept coefficients between all groups is significant at the $0.01 \%$ level $(\mathrm{P}<0.001)$.

Firstly, we summarise the common factors that affect both the 1-year and 5-year time frames for European youth adult migration intentions (see Table 4). The results of this study are in line with the literature, in terms of confirming the importance of all three categories (macro, meso and micro) of influencing factors.

At the macro level, the economic outlook (i.e., the perception of a worsening EU economy) has a significant negative impact on migration intentions. The more negative the perceived economic outlook, the higher the intention to migrate, confirming the neoclassical economic view of migration (e.g., Otrachshenko and Popova, 2014). In addition, there is a linear relationship between the transition from rural to urban areas. European young people living in urban areas (especially big cities) are more likely to migrate than those living in rural areas. This is in line with past studies on mobility intentions (Epstein and Gang, 2006). The resources (e.g., finance and information) accessible to individuals living in urban areas or larger cities may enable them to migrate more easily, or these act as platforms for internal migrants before becoming international movers (significant for the relevant micro-scale variable, although relatively low-ranked).

At the meso level, migration intentions appear to decrease where importance is placed on being with family. In addition, a higher level of satisfaction with the local community (i.e., strong community attachment) is associated with a lower migration intent. Both findings confirm Cairns' (2014) arguments that social relationships may become barriers of migration. 
Table 4: Pan-European ordinal weighted multilevel model descriptive outputs for (a) 1-year, and (b) 5-year migration intentions

\begin{tabular}{|c|c|c|c|c|c|c|c|c|c|}
\hline \multicolumn{2}{|l|}{ Parameter } & \multicolumn{4}{|c|}{ 1-Year Migration Intentions } & \multicolumn{4}{|c|}{ 5-Year Migration Intentions } \\
\hline \multirow{2}{*}{ Name } & \multirow{2}{*}{ Type } & \multirow{2}{*}{$\begin{array}{c}\text { Estimat } \\
\mathrm{e}\end{array}$} & \multirow{2}{*}{$\begin{array}{c}\text { Std. } \\
\text { Error }\end{array}$} & \multicolumn{2}{|c|}{ Significance } & \multirow{2}{*}{$\begin{array}{c}\text { Estimat } \\
\mathrm{e}\end{array}$} & \multirow{2}{*}{$\begin{array}{c}\text { Std. } \\
\text { Error }\end{array}$} & \multicolumn{2}{|c|}{ Significance } \\
\hline & & & & (1) P-Value & $(2)$ & & & (1) P-Value & $(2)$ \\
\hline Intercept: No Intentions | Unlikely & Threshold Coefficient (1|2) & 0.416 & 0.126 & $0.001 * * *$ & $\mathrm{X}$ & -0.341 & 0.142 & $0.017 *$ & $\mathrm{X}$ \\
\hline Intercept: Unlikely | Not Sure & Threshold Coefficient (2|3) & 1.539 & 0.127 & $<0.001 * * *$ & $\mathrm{X}$ & 0.581 & 0.142 & $<0.001 * * *$ & $\mathrm{X}$ \\
\hline Intercept: Not Sure | Likely & Threshold Coefficient (3|4) & 2.553 & 0.128 & $<0.001 * * *$ & $\mathrm{X}$ & 1.673 & 0.143 & $<0.001 * * *$ & $\mathrm{X}$ \\
\hline Intercept: Likely $\mid$ Concrete Arrangements & Threshold Coefficient (4|5) & 3.566 & 0.129 & $<0.001 * * *$ & $\mathrm{X}$ & 3.229 & 0.144 & $<0.001 * * *$ & $\mathrm{X}$ \\
\hline Age (Years) & Level 1: Continuous & -0.386 & 0.042 & $<0.001 * * *$ & 6 & -0.429 & 0.044 & $<0.001 * * *$ & 4 \\
\hline Gender: Male & Level 1: Binary & 0.223 & 0.065 & $0.001 * * *$ & 18 & 0.289 & 0.082 & $<0.001 * * *$ & 11 \\
\hline Migration Experience: Internal & Level 1: Binary & 0.133 & 0.029 & $<0.001 * * *$ & 27 & 0.138 & 0.028 & $<0.001 * * *$ & 24 \\
\hline Migration Experience: Born Outside Home & Level 1: Binary & 0.066 & 0.08 & 0.415 & & -0.077 & 0.083 & 0.351 & \\
\hline Migration Experience: Years Lived Abroad & Level 1: Continuous & 0.08 & 0.033 & $0.016^{*}$ & 33 & -0.004 & 0.033 & 0.903 & \\
\hline Lifestyle: Living On Your own & Level 1: Binary & 0.061 & 0.042 & 0.145 & & -0.003 & 0.041 & 0.95 & \\
\hline Lifestyle: Travel Frequency (Abroad) & Level 1: Interval & 0.781 & 0.029 & $<0.001 * * *$ & 2 & 0.51 & 0.028 & $<0.001 * * *$ & 3 \\
\hline Lifestyle: Household Financial Situation & Level 1: Interval & -0.213 & 0.03 & $<0.001 * * *$ & 21 & -0.123 & 0.029 & $<0.001 * * *$ & 29 \\
\hline Identify: Birth Region & Level 1: Interval & -0.143 & 0.029 & $<0.001 * * *$ & 25 & -0.124 & 0.028 & $<0.001 * * *$ & 28 \\
\hline Identify: World Citizen & Level 1: Interval & 0.259 & 0.029 & $<0.001 * * *$ & 10 & 0.245 & 0.028 & $<0.001 * * *$ & 14 \\
\hline Personality: Acceptable New Job Risk & Level 1: Interval & 0.249 & 0.027 & $<0.001 * * *$ & 13 & 0.294 & 0.027 & $<0.001 * * *$ & 10 \\
\hline Personality: Sensation-seeking & Level 1: Continuous & 0.306 & 0.03 & $<0.001 * * *$ & 9 & 0.327 & 0.029 & $<0.001 * * *$ & 8 \\
\hline Personality: Perseverance & Level 1: Interval & -0.012 & 0.029 & 0.681 & & -0.066 & 0.028 & $0.017 *$ & 38 \\
\hline Satisfaction: Health & Level 1: Interval & 0.032 & 0.032 & 0.309 & & 0.076 & 0.031 & $0.013 *$ & 37 \\
\hline Satisfaction: Housing & Level 1: Interval & -0.096 & 0.033 & $0.003 * *$ & 32 & -0.048 & 0.032 & 0.128 & \\
\hline Satisfaction: Family & Level 1: Interval & -0.109 & 0.032 & $0.001 * * *$ & 29 & 0.039 & 0.031 & 0.211 & \\
\hline Satisfaction: Community & Level 1: Interval & -0.111 & 0.031 & $<0.001 * * *$ & 28 & -0.146 & 0.03 & $<0.001 * * *$ & 23 \\
\hline Satisfaction: Overall Current Life & Level 1: Interval & -0.013 & 0.037 & 0.735 & & -0.258 & 0.036 & $<0.001 * * *$ & 13 \\
\hline Migration Factor: Employment Prospects & Level 1: Interval & -0.242 & 0.03 & $<0.001 * * *$ & 14 & 0.126 & 0.029 & $<0.001 * * *$ & 26 \\
\hline Migration Factor: Education & Level 1: Interval & 0.238 & 0.032 & $<0.001 * * *$ & 15 & 0.123 & 0.031 & $<0.001 * * *$ & 29 \\
\hline Migration Factor: Language Barrier & Level 1: Interval & -0.015 & 0.031 & 0.624 & & -0.129 & 0.03 & $<0.001 * * *$ & 25 \\
\hline Migration Factor: Improve Language Skills & Level 1: Interval & 0.067 & 0.033 & $0.044 *$ & 35 & 0.126 & 0.032 & $<0.001 * * *$ & 26 \\
\hline Migration Factor: Being with Family & Level 1: Interval & -0.258 & 0.032 & $<0.001 * * *$ & 11 & -0.208 & 0.031 & $<0.001 * * *$ & 18 \\
\hline Migration Factor: Being with Friends & Level 1: Interval & 0.002 & 0.033 & 0.96 & & -0.165 & 0.031 & $<0.001 * * *$ & 22 \\
\hline Migration Factor: Lifestyle/Culture & Level 1: Interval & -0.006 & 0.033 & 0.843 & & 0.078 & 0.032 & $0.014 *$ & 36 \\
\hline Migration Factor: Healthcare & Level 1: Interval & -0.1 & 0.034 & $0.003 * *$ & 31 & -0.103 & 0.033 & $0.002 * *$ & 34 \\
\hline Migration Factor: Company Policy & Level 1: Interval & 0.152 & 0.032 & $<0.001 * * *$ & 23 & 0.086 & 0.031 & $0.005 * *$ & 35 \\
\hline Migration Factor: Corruption & Level 1: Interval & 0.007 & 0.033 & 0.82 & & 0.04 & 0.032 & 0.214 & \\
\hline Migration Factor: Climate & Level 1: Interval & 0.142 & 0.031 & $<0.001 * * *$ & 26 & 0.047 & 0.03 & 0.116 & \\
\hline
\end{tabular}


Table 4 [CONTINUED] ...

\begin{tabular}{|c|c|c|c|c|c|c|c|c|c|}
\hline \multicolumn{2}{|c|}{ Parameter } & \multicolumn{4}{|c|}{ 1-Year Migration Intentions } & \multicolumn{4}{|c|}{ 5-Year Migration Intentions } \\
\hline \multirow[t]{2}{*}{ Name } & \multirow[t]{2}{*}{ Type } & \multirow{2}{*}{$\begin{array}{c}\text { Estimat } \\
\mathrm{e}\end{array}$} & \multirow{2}{*}{$\begin{array}{c}\text { Std. } \\
\text { Error }\end{array}$} & \multicolumn{2}{|c|}{ Significance } & \multirow{2}{*}{$\begin{array}{c}\text { Estimat } \\
\mathrm{e}\end{array}$} & \multirow{2}{*}{$\begin{array}{c}\text { Std. } \\
\text { Error }\end{array}$} & \multicolumn{2}{|c|}{ Significance } \\
\hline & & & & (1) P-Value & (2) & & & (1) P-Value & (2) \\
\hline Return Migrant (vs. No Prior Intent) & Level 1: Categorical (Experience) & 0.433 & 0.05 & $<0.001 * * *$ & 5 & 0.532 & 0.049 & $<0.001 * * *$ & 2 \\
\hline Researched Migration (vs. No Prior Intent) & Level 1: Categorical (Experience) & 0.667 & 0.032 & $<0.001 * * *$ & 3 & 0.873 & 0.031 & $<0.001 * * *$ & 1 \\
\hline Primary (vs. Higher Degree) & Level 1: Categorical (Education) & 0.015 & 0.143 & 0.914 & & -0.375 & 0.156 & $0.016 *$ & 6 \\
\hline Secondary (vs. Higher Degree) & Level 1: Categorical (Education) & -0.07 & 0.082 & 0.395 & & -0.229 & 0.1 & $0.023 *$ & 17 \\
\hline Post-Secondary (vs. Higher Degree) & Level 1: Categorical (Education) & -0.218 & 0.081 & $0.007 * *$ & 20 & -0.295 & 0.1 & $0.003 * *$ & 9 \\
\hline Degree (vs. Higher Degree) & Level 1: Categorical (Education) & -0.09 & 0.05 & 0.073 & & -0.11 & 0.048 & $0.023 *$ & 33 \\
\hline Married w/children (vs. Single) & Level 1: Categorical (Civil Status) & 0.077 & 0.039 & $0.049 *$ & 34 & -0.121 & 0.038 & $0.001 * *$ & 31 \\
\hline Married (vs. Single) & Level 1: Categorical (Civil Status) & -0.059 & 0.041 & 0.145 & & -0.232 & 0.039 & $<0.001 * * *$ & 16 \\
\hline Separated w/children (vs. Single) & Level 1: Categorical (Civil Status) & 0.436 & 0.122 & $<0.001 * * *$ & 4 & 0.166 & 0.12 & 0.169 & \\
\hline Separated (vs. Single) & Level 1: Categorical (Civil Status) & 0.349 & 0.175 & $0.046 *$ & 7 & -0.127 & 0.179 & 0.479 & \\
\hline Single w/children (vs. Single) & Level 1: Categorical (Civil Status) & 0.252 & 0.069 & $<0.001 * * *$ & 12 & 0.061 & 0.068 & 0.371 & \\
\hline Full-time (vs. Unemployed) & Level 1: Categorical (Employment) & -0.034 & 0.079 & 0.668 & & 0.176 & 0.077 & $0.022 *$ & 21 \\
\hline Part-time (vs. Unemployed) & Level 1: Categorical (Employment) & 0.054 & 0.081 & $\begin{array}{l}0.509 \\
\end{array}$ & & 0.24 & 0.079 & $0.002 * *$ & 15 \\
\hline Casual \& Seasonal (vs. Unemployed) & Level 1: Categorical (Employment) & 0.031 & 0.089 & 0.729 & & 0.192 & 0.087 & $0.027 *$ & 20 \\
\hline Self-employed (vs. Unemployed) & Level 1: Categorical (Employment) & -0.063 & 0.089 & 0.477 & & 0.155 & 0.087 & 0.075 & \\
\hline Job seeking (vs. Professional) & Level 1: Categorical (Occupation) & 0.225 & 0.087 & $0.01 *$ & 17 & 0.356 & 0.085 & $<0.001 * * *$ & 7 \\
\hline Clerical \& Administrative (vs. Professional) & Level 1: Categorical (Occupation) & 0.005 & 0.049 & 0.925 & & -0.038 & 0.047 & 0.416 & \\
\hline House-person \& Caring (vs. Professional) & Level 1: Categorical (Occupation) & -0.126 & 0.103 & 0.222 & & 0.147 & 0.099 & 0.137 & \\
\hline Other (vs. Professional) & Level 1: Categorical (Occupation) & -0.046 & 0.063 & \begin{tabular}{|l|l|}
0.467 \\
\end{tabular} & & -0.091 & 0.06 & 0.13 & \\
\hline Other Manual (vs. Professional) & Level 1: Categorical (Occupation) & 0.227 & 0.06 & $<0.001 * * *$ & 16 & 0.068 & 0.058 & 0.24 & \\
\hline Skilled Manual (vs. Professional) & Level 1: Categorical (Occupation) & 0.183 & 0.052 & $<0.001 * * *$ & 22 & 0.096 & 0.05 & 0.055 & \\
\hline City (vs. Rural) & Level 1: Categorical (Living Area) & 0.148 & 0.039 & $<0.001 * * *$ & 24 & 0.208 & 0.038 & $<0.001 * * *$ & 18 \\
\hline Town (vs. Rural) & Level 1: Categorical (Living Area) & -0.008 & 0.038 & 0.826 & & 0.117 & 0.037 & $0.001 * *$ & 32 \\
\hline Origin-Destination EU25 (vs. Destination & Level 1: Categorical (EU Migration & 0.345 & 0.085 & $<0.001 * * *$ & 8 & 0.286 & 0.101 & $0.005 * *$ & 12 \\
\hline Origin EU25 (vs. Destination EU15) & Level 1: Categorical (EU Migration & 0.401 & 0.209 & 0.055 & & -0.075 & 0.244 & 0.759 & \\
\hline Origin EU27 (vs. Destination EU15) & Level 1: Categorical (EU Migration & 1.094 & 0.274 & $<0.001 * * *$ & 1 & 0.375 & 0.318 & 0.238 & \\
\hline Eurobarometer: Understand EU Workings & Level 2: Continuous & -0.165 & 0.091 & 0.068 & & -0.124 & 0.093 & 0.183 & \\
\hline Eurobarometer (P): Worse Personal Job & Level 2: Continuous & -0.019 & 0.053 & 0.717 & & 0.061 & 0.056 & 0.274 & \\
\hline Eurobarometer (P): Worse EU Economy (\%) & Level 2: Continuous & 0.22 & 0.1 & $0.027 *$ & 19 & 0.388 & 0.105 & $<0.001 * * *$ & 5 \\
\hline Eurobarometer: Favour National Austerity & Level 2: Continuous & -0.106 & 0.048 & $0.026 *$ & 30 & 0.004 & 0.047 & 0.934 & \\
\hline Eurobarometer: Strong National Identity (\%) & Level 2: Continuous & 0.062 & 0.08 & 0.437 & & 0.046 & 0.083 & 0.585 & \\
\hline Eurostat: NUTS 1 Gross Domestic Product & Level 2: Continuous & -0.105 & 0.069 & 0.127 & & -0.041 & 0.083 & 0.625 & \\
\hline Eurostat: NUTS 0 Gross Domestic Product & Level 3: Continuous & 0.095 & 0.208 & 0.646 & & -0.37 & 0.239 & 0.122 & \\
\hline
\end{tabular}

$(P)=$ Perceptions within the next 12-months; *** Significant at the $0.1 \%$ level $(P<0.001) ; * *$ Significant at the $1 \%$ level $(P<0.01) ; *$ Significant at the $5 \%$ level $(P<0.05)$ 
At the micro level, a larger number of significant motives of and barriers to migration are identified. Firstly, when thinking about a household's financial situation, individuals who struggle to make ends meet every month, and persons who were seeking jobs (in comparison to having professional jobs) are more likely to migrate. These findings echo the neoclassical economic view of migration with respect to unemployment, and is consistent with the finding of this study at the macro level. Secondly, this study confirms Boneva and Frieze's (2001) notion of the importance of migrant personality. In particular, those who consider they have a greater propensity for sensation-seeking are more likely to migrate, in line with Williams and Baláž's (2012) findings about the related concept of willingness to take risk. Respondents who identify themselves as world citizens have stronger migration intentions, while those with a strong identity with their birth region were more likely to remain, confirming the findings of Bjarnason and Thorlindsson (2006) and Van Dalen and Henkens (2012). Thirdly, migration intentions were likely to be greater for individuals seeking to enhance their language skills and general education. This is in line with the notion that migration represents investment in human capital (Sjaastad, 1962). The human capital theory also supports the finding that persons with a higher degree are more likely to migrate, as observed by other researchers (Fassmann and Hintermann, 1998; Epstein and Gang, 2006). Fourthly, individuals with lower quality of life are more likely to migrate, suggesting migration is related to a lifestyle choice, as also evidenced by Baláž et al. (2016). Fifthly, those who place a high importance on healthcare are less likely to migrate. Both findings suggest the existence of important barriers to migration intentions. Lastly, socio-demographic variables have some effects on European young people's migration intentions. In particular, younger male persons with past internal mobility experience are more likely to migrate, which once again confirms previous research findings (e.g., Epstein and Gang, 2006; Van Mol, 2016).

Next, we identify the top five significant factors for migration intentions over the next 1 and 5 years, respectively, based on the estimates in Table 4. Taking first the 1-year intentions, and the pan-European analysis, the top five factors influencing a young person's intention to move abroad within the next year are:

1) Origin EU27 vs. Destination EU15 (+)

2) Lifestyle: Travel Frequency Abroad (+)

3) Researched Migration vs. No Prior Intent (+)

4) Separated w/children vs. Single (+)

5) Returned Migrant vs. No Prior Intent (+)

The signs in the parentheses suggest either positive (+) or negative (-) effects of these variables on the intention. The estimates in the output table are provided in units of ordered logits, which are exponentially transformed into odds ratios for the purpose of further interpretation. The odds ratio represents the impact of a unit change in an independent variable (when all other independent variables in the model are held constant) on the ratio of the probability of an event occurring, represented by the binary scale of $1=$ Migrate and $0=$ Remain. An odds ratio greater than 1 indicates that the odds of migrating increase with the independent $(\mathrm{X})$ variable, and vice versa:

- Origin EU27 vs. Destination EU15: EXP (1.094) = 2.986; in other words, the odds for people from Romania expressing an intention to migrate within one year are 198.6\% higher than those from Germany, Sweden or the UK; 
- Travel Frequency Abroad (+1 Likert scale): $\operatorname{EXP}(0.781 /(2 * 1.146))=1.406 ;$ in other words, the odds increases by $40.6 \%$ as travel frequency increases by 1 unit on a 6-point Likert scale;

- Researched Migration vs. No Prior Intent: EXP (0.667) = 1.948; in other words, the odds for people who have researched migration options are $94.8 \%$ higher than those who have never thought about migration before;

- $\quad$ Separated with children: $\operatorname{EXP}(\mathbf{0 . 4 3 6})=1.546$; in other words, the odds for those who are separated with children are $54.7 \%$ higher than people who are single and without children;

- Returned Migrant vs. No Prior Intent: EXP $(\mathbf{0 . 4 3 3})=\mathbf{1 . 5 4 2}$; in other words, the odds for people who are returned migrants are $54.2 \%$ higher than those who have never previously considered migration, indicating the importance of either pre-disposition or acquired migration knowledge (Williams \& Baláž, 2012).

Moving now to 5-year intentions, in the pan-European analysis, the top five most influential factors are:

1) Researched Migration vs. No Prior Intent (+)

2) Returned Migrant vs. No Prior Intent (+)

3) Lifestyle: Travel Frequency Abroad (+)

4) Age in Years

5) Eurobarometer (Next 12-Months): Worsening EU Economy (+)

As with the one-year model, they are interpreted as follows:

- Researched Migration vs. No Prior Intent: EXP (0.873) = 2.394; in other words, the odds for people who have researched migration options are $139.4 \%$ higher than those who have never thought about migration before;

- Returned Migrant vs. No Prior Intent: EXP (0.532) = 1.702; in other words, the odds for people who are returned migrants are $70.2 \%$ higher than those who have never thought about migration before;

- Travel Frequency Abroad (+1 Likert scale): EXP $(0.51 /(2 * 1.146))=1.249$; in other words, the odds increases by $24.9 \%$ as travel frequency increases by 1 unit on a 6-point Likert scale;

- Age (+1 year): EXP $(\mathbf{- 0 . 4 2 9} /(\mathbf{2} * \mathbf{4 . 7 5 3}))=\mathbf{0 . 9 5 6}$; in order words, the odds decreases by $4.4 \%$ as age increase by 1 year;

- Declining EU Economy: EXP $(0.388 /(2 * 38.334))=1.005$; in order words, the odds increases by $0.5 \%$ for a 1 -unit increase in the percentage of people who perceive the EU economy will worsen in the next 12-months.

Three of the five main factors are the same over the two time frames, but concerns over the EU economy are more important over the longer term, which may reflect greater uncertainty over this time scale. The absence of 'Origin EU27 and Destination EU15' from the top five factors over five years, may reflect a potential peaking of this particular migration flow, related to the relatively recent ending of transitional freedom of movement arrangements for Romania (and Bulgaria). Additionally, Table 4 discloses more differences in the influencing factors between the two time frames. For example, life satisfaction with housing and family domains only affects migration intention over the next year, while satisfaction with heath, 
overall life satisfaction and having a perseverance personality only have significant effects on migration intention over the next five years. Employed persons are more likely to intend to migrate than unemployed persons only over five years, which resonates with the findings about perceived macro-economic conditions, while occupational differences seem to affect the intention to migrate over one year. Finally, language barriers and staying with friends become barriers for intentions to migrate for the five-year time frame.

\section{Hierarchical effects}

The fixed effects models (Table 4) show that, at an individual response level, migration intentions for males within the next one and five years are higher than for females, by $25.0 \%$ $($ Odds Ratio: $\operatorname{EXP}(0.223)=1.249)$ and $33.5 \%($ Odds Ratio: $\operatorname{EXP}(0.289)=1.335)$ respectively. In terms of education, an individual with a basic level of education is most likely to migrate within the next year, while those with a higher degree are most likely to migrate within the next five years.

Hierarchical structures within the multi-level model also consider the collective response of members from demographic sub-populations, based on education, age and gender group interactions (Table 5). The results show that the individual effects of gender and education are modified somewhat at an ecological level. The highest 1-year and 5-year migration intentions appear in the 'female 26-35-year medium education' subpopulation $(+10.2 \%$ and $21.4 \%)$, even if males overall have higher mobility plans.

Table 5: Level-2 hierarchical structure coefficients and likelihoods (\%) values for the PanEuropean demographic sub-populations

\begin{tabular}{|c|c|c|c|c|}
\hline \multirow[b]{2}{*}{ Sub-Population Unit } & \multicolumn{2}{|c|}{ 1-Year Migration Intention } & \multicolumn{2}{|c|}{ 5-Year Migration Intention } \\
\hline & Coefficient & Likelihood (\%) & Coefficient & Likelihood (\%) \\
\hline \multirow{4}{*}{$\begin{array}{l}\text { 16-25 Female ED0-2 } \\
\text { 16-25 Male ED0-2 } \\
\text { 26-35 Female ED0-2 } \\
\text { 26-35 Male ED0-2 }\end{array}$} & 0.015 & $1.48 \%$ & -0.036 & $-3.51 \%$ \\
\hline & -0.018 & $-1.79 \%$ & -0.054 & $-5.25 \%$ \\
\hline & -0.012 & $-1.15 \%$ & -0.045 & $-4.36 \%$ \\
\hline & 0.015 & $1.52 \%$ & 0.137 & $14.63 \%$ \\
\hline \multirow{4}{*}{$\begin{array}{l}\text { 16-25 Female ED3-4 } \\
\text { 16-25 Male ED3-4 } \\
\text { 26-35 Female ED3-4 } \\
\text { 26-35 Male ED3-4 }\end{array}$} & 0.096 & $10.02 \%$ & 0.194 & $21.4 \%$ \\
\hline & -0.023 & $-2.25 \%$ & -0.039 & $-3.86 \%$ \\
\hline & -0.041 & $-4 \%$ & -0.079 & $-7.58 \%$ \\
\hline & -0.031 & $-3.07 \%$ & -0.074 & $-7.13 \%$ \\
\hline \multirow{4}{*}{$\begin{array}{l}\text { 16-25 Female ED5-8 } \\
\text { 16-25 Male ED5-8 } \\
\text { 26-35 Female ED5-8 } \\
\text { 26-35 Male ED5-8 }\end{array}$} & -0.03 & $-2.97 \%$ & 0.025 & $2.55 \%$ \\
\hline & 0.049 & $4.99 \%$ & 0.065 & $6.69 \%$ \\
\hline & -0.027 & $-2.64 \%$ & -0.054 & $-5.27 \%$ \\
\hline & 0.009 & $0.9 \%$ & -0.031 & $-3.1 \%$ \\
\hline
\end{tabular}

Figure 4 presents the exponentially transformed spatial ecological unit coefficients from the pan-European multi-level models, as a percent of increased/decreased intent to migrate within (a) 1-year or (b) 5-years. Mapped outputs represent the combined influence of Level-2 (NUTS 1: macro-region) and Level 3 (NUTS0: national) spatial differences in migration intentions. NUTS 1 (macro-region) level populations in Southern Spain and Italy generally exhibit strong youth migration intentions, and are $>5 \%$ more likely to migrate within the next year, perhaps a consequence of prevailing high unemployment levels. In Italy, the reverse is observed for 5 -year intentions, which are $<-5 \%$ lower than the expected level of 
intent recorded in a European macro-region, perhaps indicating greater optimism for longerterm economic and social trajectories. Comparison of the 1-year and 5-year periods, reveals a change in the direction of migration intent, from negative to positive, for residents of Ireland, Wales and the South East of England, perhaps indicating the importance of uncertainties concerning the longer (five year) period in these regions.

\section{National comparisons}

For each national subset of the survey, two multi-level models are constructed which explore the (a) 1-year and (b) 5-year migration intentions. National models for 1-year migration intentions return Nagelkerke pseudo-R- measures of 0.27-0.37, with the 5-year intention models recorded at $0.27-0.51$. The top 5 most influential modelled parameters that are significant $(\mathrm{P}<0.05)$ in each of the national models are summarised in Table 6.

Various differences between the two time horizons and among the nine countries can be seen among the top 5 influencing factors presented in Table 6. These key influences tend to be similar for countries within three European geographic zones (Northern, Southern, and Eastern). The preceding hierarchical cluster identified the Southern and Eastern European countries as having common attributes, the effects of which are shown to differ in magnitude and direction by geographic region in the regression analysis. Given the more significant potential implications of the five-year migration intention, the following national comparisons focus on this set of results. Firstly, opposite signs of effects are found in a couple of cases, particularly between Romania and other countries. Unemployed persons are more likely to migrate in Romania than persons taking casual or seasonal jobs, while the opposite is true in Spain; women are more likely to migrate than men in Romania, while men are more likely to migrate than women in Ireland. Recent studies conducted in Ireland confirm high mobility intentions among men (Cairns and Smyth, 2011; Van Mol, 2016). Persons born out of the home country are more likely to migrate in Sweden, but less likely in Romania. Romanian young persons with primary education are more likely than those with higher degrees to migrate, while Irish young people with higher degrees are more likely to migrate than those with primary degrees. Perception of a worsening national economy is the top driver of migration in Latvia; the job-seeking occupational status in comparison to being employed in a professional position is the top predictor of migration in Romania; 'understanding of how the EU works' is the second most important driver to migrate for Romanian young persons. These findings suggest that, for the key migration-origin countries, economic reasons still play an important role in shaping migration intentions, as suggested by the neoclassical view (consistent also with the findings of Baláž et al., 2016). In addition, more consistent findings can be seen within the geographical zones, for example, between Spain and Italy in Southern Europe, and between Germany and the UK in Northern Europe. In particular, the sensation-seeking personality plays a more important role in Germany and the UK than in other countries.

A series of "Two-Way ANOVA" models were used to determine whether statistically significant differences exist between the national migration intention models, grouped by (1) Geographic Zone and (2) intention timeframes. The analysis evaluated the 42 coefficients present in each national model. The overall null hypothesis (H0) states that the population means for countries located in different geographic zones are equal across both periods of time, while the alternative hypothesis (H1) states that at least one group's response is significantly different. Table 7 presents the ANOVA Tukey Honest Significant Difference (HSD) post-hoc results. 
Figure 4: Exponentially transformed spatial ecological unit coefficients from the Pan-European multilevel models, as a percent of increased/decreased intent to migrate within (a) 1-year or (b) 5-years.
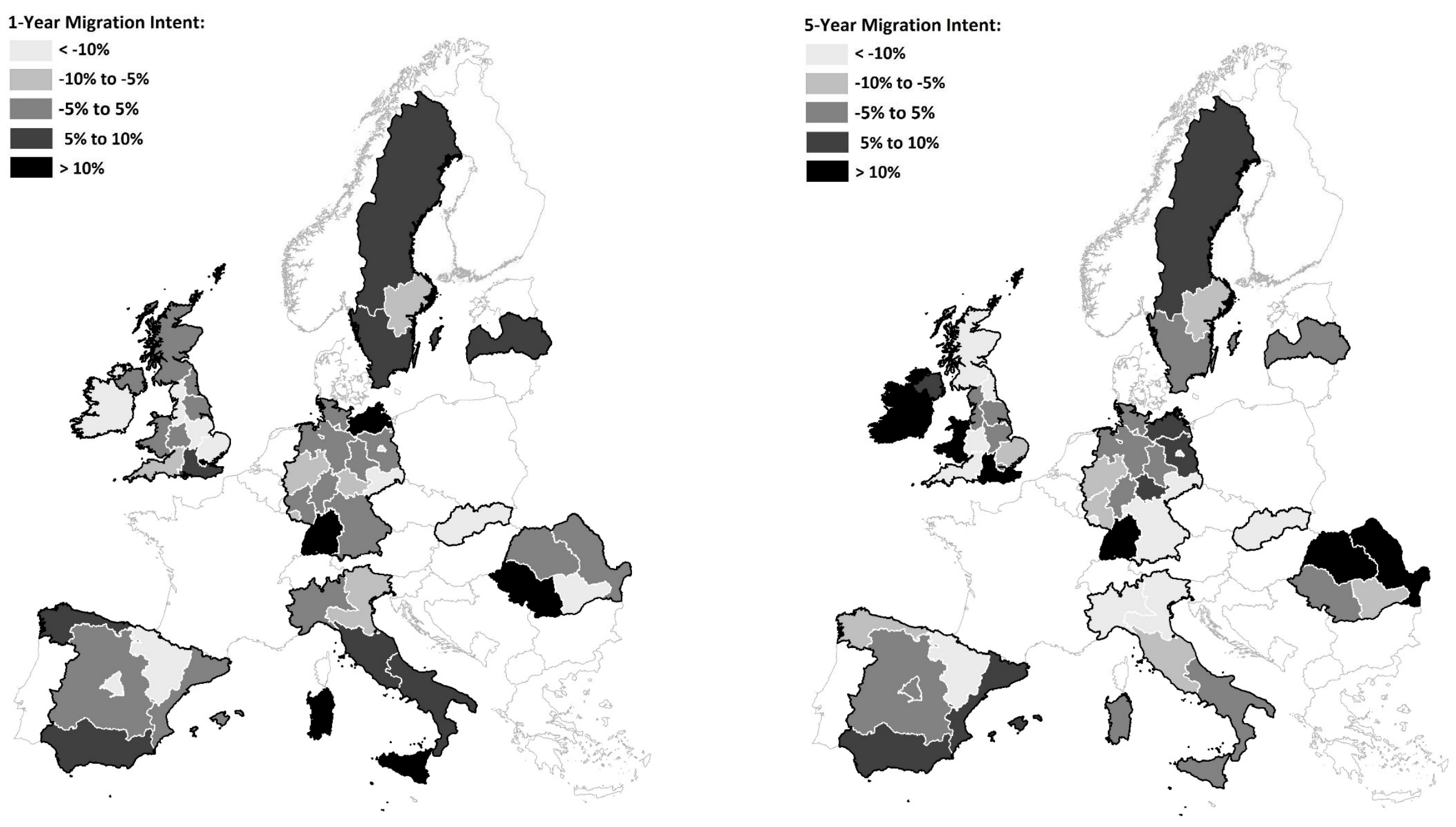
Table 6: Top-5 significant modelled influences on 1-year and 5-year migration intentions (with influence direction), obtained from the national ordinal weighted multilevel models

\begin{tabular}{|c|c|c|c|c|c|c|c|c|c|c|c|c|c|c|c|c|c|c|}
\hline \multirow[b]{2}{*}{ PARAMETER } & \multicolumn{9}{|c|}{ 1-YEAR INTENTIONS } & \multicolumn{9}{|c|}{ 5-YEAR INTENTIONS } \\
\hline & DE & IE & SE & UK & ES & IT & $\mathbf{L V}$ & RO & SK & DE & IE & SE & UK & ES & IT & $\mathbf{L V}$ & RO & SK \\
\hline Age (Years) & & & & & & & & & & $4(-)$ & & & $5(-)$ & & & & & \\
\hline Casual \& Seasonal (vs. Unemployed) & & & & & & & & & & & & & & $1(+)$ & & & $5(-)$ & \\
\hline Current Life Satisfaction & & & & & & & & & & $5(-)$ & & & & & & & & \\
\hline Full-time (vs. Unemployed) & & & & & & & $2(-)$ & & & & & & & & & & & \\
\hline Gender: Male & & $2(+)$ & $4(+)$ & & & & & $5(+)$ & & & $2(+)$ & & & & & & $3(-)$ & \\
\hline House-person \& Caring (vs. Professional) & $3(-)$ & & & & & & & & & & & & & & & & & \\
\hline Identify: World Citizen & & & & $5(+)$ & & & & & & & & & & & & & & \\
\hline Job seeking (vs. Professional) & & & & & & & & & & & & & & & & & & $1(+)$ \\
\hline Lifestyle: Travel Frequency (Abroad) & $2(+)$ & & & $1(+)$ & $2(+)$ & $3(+)$ & & & & $3(+)$ & & & $2(+)$ & $4(+)$ & $5(+)$ & & & \\
\hline Married w/children (vs. Single) & & & & & & & & & $3(-)$ & & & & & & & & & $2(-)$ \\
\hline Migration Experience: Born Outside Home Country & & & & & & & & & & & & $2(+)$ & & & & & $4(-)$ & \\
\hline Migration Factor: Being with Family & & & & & & & & & & & & & & & & $5(-)$ & & \\
\hline Other Manual (vs. Professional) & & & & & & & & & $4(+)$ & & & & & & & $3(+)$ & & \\
\hline Part-time (vs. Unemployed) & & & & & & & $5(-)$ & & & & & & & $5(+)$ & & & & \\
\hline Personality: Acceptable New Job Risk (Financial) & & & & & $5(+)$ & & & & & & & & & & & & & \\
\hline Personality: Risk Response Ability & & & & & $4(+)$ & & & & & & & & & & & & & \\
\hline Personality: Sensation-seeking & & & & $4(+)$ & & & & & & $2(+)$ & & & $4(+)$ & & & & & \\
\hline Post-Secondary (vs. Higher Degree) & & $5(+)$ & $2(+)$ & & & & & $2(+)$ & & & & & & & & & & \\
\hline Primary (vs. Higher Degree) & & $1(-)$ & & & & & & & & & $1(-)$ & & & & & & $1(+)$ & \\
\hline Researched Migration (vs. No Prior Intent) & $4(+)$ & & & $2(+)$ & $3(+)$ & $2(+)$ & & & & $1(+)$ & & $4(+)$ & $1(+)$ & $2(+)$ & $3(+)$ & $2(+)$ & & $5(+)$ \\
\hline Return Migrant (vs. No Prior Intent) & & & & & & $4(+)$ & & & & & & & $3(+)$ & & $4(+)$ & $4(+)$ & & $4(+)$ \\
\hline Satisfaction: Community & $5(-)$ & & & & & & & & & & & & & & & & & \\
\hline Secondary (vs. Higher Degree) & & & $1(+)$ & & & & & $1(+)$ & & & $5(+)$ & & & & & & & \\
\hline Self-employed (vs. Unemployed) & & & & & & & $4(-)$ & & & & & $3(-)$ & & & & & & \\
\hline Separated (vs. Single) & & & & & & & $1(+)$ & & $1(+)$ & & & & & & & & & \\
\hline Separated w/children (vs. Single) & $1(+)$ & & $3(+)$ & & & $1(-)$ & $3(+)$ & & $2(-)$ & & & & & & $2(-)$ & & & $3(-)$ \\
\hline Single w/children (vs. Single) & & & & & $1(+)$ & $5(+)$ & & & $5(-)$ & & & $5(+)$ & & $3(+)$ & & & & \\
\hline Skilled Manual (vs. Professional) & & & & $3(+)$ & & & & & & & & & & & & & & \\
\hline Eurobarometer (Next 12-Months): Worse National Economy (\%) & & & & & & & & & & & & & & & & $1(+)$ & & \\
\hline Eurobarometer: Good National Economy (\%) & & $3(-)$ & & & & & & $4(-)$ & & & $4(-)$ & & & & & & & \\
\hline Eurobarometer: Good National Employment Level (\%) & & $4(-)$ & & & & & & & & & $3(-)$ & & & & $1(-)$ & & & \\
\hline Eurobarometer: Good Personal Job Situation (\%) & & & & & & & & & & & & $1(-)$ & & & & & & \\
\hline Eurobarometer: Non-EU Immigration is Positive (\%) & & & $5(+)$ & & & & & & & & & & & & & & & \\
\hline Eurobarometer: Trust The National Legal System (\%) & & & & & & & & $3(+)$ & & & & & & & & & & \\
\hline Eurobarometer: Understand EU Workings (\%) & & & & & & & & & & & & & & & & & $2(+)$ & \\
\hline
\end{tabular}


With regard to geographical differences, the results suggest that, persons employed in "Clerical", "Other Manual", and "Other: Undefined" occupations in Eastern European countries, are more likely to migrate than those from similar occupations in Northern Europe; persons who perceive themselves as risk-takers in Northern and Southern European countries, are more likely to migrate than risk-takers from Eastern European countries; those that identify themselves as world citizens in Northern European countries are more likely to migrate than world citizens from Eastern European countries; persons from Eastern European countries with a good household financial situation are less likely to migrate than their counterparts from Northern of Southern European countries.

Table 7: Two-Way ANOVA post-hoc analysis, identifying significant differences in migration intentions between the national models by (1) Geographic Zone ("Northern", "Southern" and "Eastern") and (2) Intention Timeframe ("1-Year" and "5-Years")

\begin{tabular}{|l|l|c|}
\hline $\begin{array}{l}\text { Two-Way ANOVA } \\
\text { (3x Geographic Zones, 2x Timeframes) }\end{array}$ & Tukey HSD Comparison & $\begin{array}{c}\text { Mean Coefficient } \\
\text { Difference }\end{array}$ \\
\hline \multirow{2}{*}{ Travel Frequency (Abroad) } & (1) Northern vs. (2) Eastern & Higher $(* *)$ \\
\cline { 2 - 3 } & (1) Southern vs. (2) Eastern & Higher $(*)$ \\
\cline { 2 - 3 } & (1) 5-Years vs. (2) 1-Year & Lower $(*)$ \\
\hline \multirow{2}{*}{ Household Financial Situation } & (1) Northern vs. (2) Eastern & Higher $(* * *)$ \\
\cline { 2 - 3 } & (1) Southern vs. (2) Eastern & Higher $(* *)$ \\
\hline Identify: World Citizen & (1) Northern vs. (2) Eastern & Higher $(*)$ \\
\hline Personality: Risk-seeking & (1) Northern vs. (2) Eastern & Higher $(* *)$ \\
\cline { 2 - 3 } & (1) Southern vs. (2) Eastern & Higher $(*)$ \\
\hline Migration Factor: Education & (1) 5-Years vs. (2) 1-Year & Lower $(*)$ \\
\hline Researched Migration vs. No Prior Intent & (1) 5-Years vs. (2) 1-Year & Higher $(*)$ \\
\hline Clerical \& Administrative vs. Professional & (1) Northern vs. (2) Eastern & Lower $(* *)$ \\
\hline Other vs. Professional & (1) Northern vs. (2) Eastern & Lower $(* * *)$ \\
\hline \multirow{2}{*}{ Other Manual vs. Professional } & (1) Northern vs. (2) Eastern & Lower $(* * *)$ \\
\cline { 2 - 3 } & (1) Southern vs. (2) Eastern & Lower $(* * *)$ \\
\hline
\end{tabular}

*** Significant at the $0.1 \%$ level $(P<0.001)$; ** Significant at the $1 \%$ level $(P<0.01)$; * Significant at the $5 \%$ level $(P<$ 0.05).

Some differences are also found between the 1-year and 5-year intention timeframes. For example, travel frequency has a significantly lower influence on long term migration intentions; education has a greater influence on long term migration decisions; persons that have extensively researched migration are more likely to migrate in the next 5-years, than take immediate action.

\section{CONCLUSIONS}

Based on a large-scale online survey, supplemented by selected aggregate socio-economic indicators, and using ordinal multi-level regression analysis, this study examines various motivation factors and barriers of European young people's migration intentions over the next year and five years. In this paper we focus specifically on non-student respondents aged 16-35 years.

The study findings reveal that, within a year, 17 per cent of respondents in the panEuropean sample of non-student respondents aged 16-35 are likely to migrate, with a 
substantial minority having made concrete plan to do so. The results vary among the nine countries, with the respondents in Romania showing the highest intention $(21 \%)$ and those in Ireland, Slovakia and Latvia the lowest (13\%). Mobility intentions among the nine European countries significantly increase when changing the time-scale to five years. As many as 30 per cent of the respondents across all countries are either likely to migrate or have made concrete plans already. Again, Romanian respondents show the highest migration intention in five years (41\%), followed by Italy (39\%) and Spain (35\%). Slovakian respondents display the lowest intention to migrate (22\%), followed by the respondents from the UK $(25 \%)$, and Ireland and Latvia (both 26\%). These findings are particularly surprising in the case of Ireland given its history of emigration, and also indicate differences between the A8 and A2 member states included in this survey.

Our findings confirm that Romania seems to be emerging as an important emigration nation, and that is rooted in the economic factors emphasised in neoclassical approaches to migration (Todaro, 1969). Individuals struggling to secure their livelihood in their home country, those with no income and no qualifications are most likely to have plans to migrate. Considering that Romania has only recently gained full access to the EU labour market, emigration to the more developed countries may continue at relatively high levels for some years. On the other hand, the two A8 countries, Latvia and Slovakia, which became EU members in 2004, display much lower mobility intentions. This raises the question of whether their peak emigration flows have passed - at least for the foreseeable future - due to changes in opportunities and living standards in their home countries.

There are significant barriers to mobility; in particular, strong family attachment is an important meso-level determinant. Confirming recent studies (Cairns, 2014; Van Mol, 2016), migration intentions decrease where importance is placed on being with family. Turning to micro-level determinants of intentions, our study reveals that a number of non-economic motives are also important. In terms of demographic factors, potential European migrants are more likely to be men, younger, urban and highly educated and with past internal mobility experience. Nevertheless, national differences can be observed. For example, Romania again seems to display different characteristics, with women, and those with lower education, more likely to express intentions to leave. Supporting more recent research on the existence of a 'migrant personality' (Boneva and Frieze, 2001; Van Dalen and Henkens, 2012), this study also indicates that the sensation-seeking personality plays an important role in willingness to migrate, especially in Germany and the UK. Indeed, a cross-country comparison among the nine survey countries identified that there were both country-specific influencing factors of youth migration, and also some statistically significant differences at the macro-regional level (Northern, Southern and Eastern) between these.

The analysis of future migration trajectories has long been a central issue for national and regional policy analysts, concerned with the implications of both emigration and immigration. This paper has above all identified the high level of commitment to future international migration within the EU, as well as differences across macro-regions, and between individual countries. This signifies that any future realignment of international migration controls either at the level of individual countries (such as in post-Brexit UK) or at the EU level, is likely to have major implications for potential migrants, and for the relative size and composition of the flows to particular destination countries. But it also suggests that the effects of any regulatory changes will be mediated by the complex set of established, interrelated drivers of migration. 


\section{REFERENCES}

Agadjanian V, Nedoluzhko L, Kumskov G. 2008. Eager to leave? Intentions to migrate abroad among young people in Kyrgyzstan. International Migration Review 42: 620-651.

Agresti A. 2002. Categorical Data Analysis. John Wiley: New Jersey.

Ajzen I. 1991. The theory of planned behaviour. Organizational Behaviour and Human Decision Processes 50: 179-211.

Baláž V, Williams AM, Fifeková E. 2016. Migration decision making as complex choice: eliciting decision weights under conditions of imperfect and complex information through experimental methods. Population, Space and Place 22: 36-53.

Boneva BS, Frieze IH. 2001. Toward a concept of a migrant personality. Journal of Social Issues 57: 477-491.

Boyd M. 1989. Family and personal networks in international migration: recent developments and new agendas. International Migration Review 23: 638-670.

Cairns D. 2010. Youth on the Move: European Youth and Geographical Mobility. Springer: Wiesbaden.

Cairns D. 2014. 'I wouldn't stay here': economic crisis and youth mobility in Ireland. International Migration 52: 236-249.

Cairns D, Growiec K, Smyth J. 2013. Leaving Northern Ireland: youth mobility, field, habitus and recession among undergraduates in Belfast, British Journal of Sociology of Education 34: 544-562.

Cairns D, Smyth J. 2011. I wouldn't mind moving actually: exploring student mobility in Northern Ireland. International Migration 49: 135-161.

Christensen R. 2015. Ordinal - Regression Models for Ordinal Data. R package version 2015.6-28. Available at: https://cran.r-project.org/web/packages/ordinal/ordinal.pdf (accessed 31.01.2017).

Ciobanu OR. 2015. Multiple migration flows of Romanians. Mobilities 10: 466-485.

De Jong GF. 2000. Expectations, gender, and norms in migration decision-making. Population Studies 54: 307-319.

Docquier F, Peri G, Ruyssen I. 2014. The cross-country determinants of potential and actual migration. International Migration Review 48: S37-S99.

Eurostat Database (2017). Eurostat Database, available at: http://ec.europa.eu/eurostat/data/database (accessed 31.01.2017).

Epstein GS, Gang IN. 2006. The influence of others on migration plans. Review of Development Economics 10: 652-665.

Fassmann H, Hintermann C. 1998. Potential east-west migration, demographic structure, motives and intentions. Czech Sociological Review 6: 59-72.

Finch W, Bolin J, Kelley K. 2014. Multilevel Modelling Using R. CRC Press: Florida.

Frieze IH, Hansen SB, Boneva B. 2006. The migrant personality and college students' plans for geographic mobility. Journal of Environmental Psychology 26: 170-177.

Galwey N. 2007. Introduction to Mixed Modelling: Beyond Regression and Analysis of Variance. Wiley: London. 
Gelman A, Hill J. 2006. Data Analysis Using Regression and Multilevel/Hierarchical Models (Analytical Methods for Social Research). Cambridge University Press: Cambridge.

Ghitza Y, Gelman A. 2013. Deep interactions with MRP: election turnout and voting patterns among small electoral subgroups. American Journal of Political Science 57: 762-776.

Gubhaju B, De Jong GF. 2009. Individual versus household migration decision rules: Gender and marital status differences in intentions to migrate in South Africa. International Migration 47: 31-61.

Hadler M. 2006. Intentions to migrate within the European Union: a challenge for simple economic macro-level explanations. European Societies 8: 111-140.

Halfacree, K. 2004. A utopian imagination in migration's terra incognita? acknowledging the non-economic worlds of migration decision-making. Population Space Place 10: 239253.

Hox J. 1998. Multilevel modelling: when and why. In Classification, Data Analysis, and Data Highways, Balderjahn I, Mathar R, Schader M. (eds.) Springer: New York; 147154.

King R, Findlay A, Ahrens J. 2010. International Student Mobility Literature Review. Project Report. Higher Education Funding Council for England (HEFCE), Bristol.

Jokela M. 2009. Personality predicts migration within and between U.S. states. Journal of Research in Personality 43: 79-83.

Lax J, Phillips J. 2009a. How should we estimate public opinion in the states? American Journal of Political Science 53: 107-121.

Lax J, Phillips J. 2009b. Gay rights in the states: public opinion and policy responsiveness. American Journal of Political Science 103: 367-386.

Main I. 2014. High mobility of Polish women: the ethnographic inquiry of Barcelona. International Migration 52: 130-145.

Massey DS, Arango J, Hugo JG, Kouaouci A, Pellegrino A, Taylor JE. 1993. Theories of International migration: a review and appraisal. Population and Development Review 19: $431-466$.

Nagelkerke N. 1991. A note on a general definition of the coefficient of determination. Biometrika 78: 691-692.

Otrachshenko V, Popova O. 2014. Life (dis) satisfaction and the intention to migrate: evidence from Central and Eastern Europe. The Journal of Socio-Economics 48: 40-49.

Pietka-Nykaza E, McGhee D. 2016. EU post-accession Polish migrants trajectories and their settlement practices in Scotland. Journal of Migration and Ethnic Studies, http://dx.doi.org/10.1080/1369183X.2016.1241137

Schuenemeyer J, Drew L. 2011. Statistics for Earth and Environmental Scientists. John Wiley: New Jersey.

Sjaastad L. 1962. The costs and returns of human migration. Journal of Political Economy 70: 80-93.

Suzuki R, \& Shimodaira H. 2006. Pvclust: An R package for assessing the uncertainty in hierarchical clustering. Bioinformatics. 22(12): 1540-1542 
Tabor AS, Milfont TL. 2011. Migration change model: Exploring the process of migration on a psychological level. International Journal of Intercultural Relations 35: 818-832.

Tabor AS, Milfont TL, Ward C. 2015. The migrant personality revisited: individual differences and international mobility intentions. New Zealand Journal of Psychology 44: 89-95.

Todaro MP. 1969. A model of labour migration and urban unemployment in less developed countries. The American Economic Review 59: 138-148.

Tukey J. 1949. Comparing Individual Means in the Analysis of Variance. Biometrics 5: 99114.

Van Dalen HP, Groenewold G, Schoorl JJ. 2005. Out of Africa: what drives the pressure to emigrate?. Journal of Population Economics 18: 741-778.

Van Dalen HP, Henkens K. 2007. Longing for the good life: understanding emigration from a high-income country. Population and Development Review 33: 37-66.

Van Dalen HP, Henkens K. 2008. Emigration intentions: mere words or true plans? Explaining international migration intentions and behavior. available at: http://iussp2009.princeton.edu/papers/90831 (accessed 31.01.2017).

Van Dalen HP, Henkens K. 2012. Explaining low international labour mobility: the role of networks, personality, and perceived labour market opportunities, Population, Space and Place 18: 31-44.

Van Mol C. 2016. Migration aspirations of European youth in times of crisis. Journal of Youth Studies 19: 1303-1320.

Van Mol C, Timmerman C. 2014. Should I stay or should I go? An analysis of the determinants of intra-European student mobility. Population, Space and Place 20: 465-479.

Williams AM, Baláž V. 2012. Migration, risk, and uncertainty: theoretical perspectives.

Population, Space and Place 18: 167-180. 